\title{
Comparing Floristic Diversity between a Silviculturally Managed Arboretum and a Forest Reserve in Dambulla, Sri Lanka
}

\author{
B. D. Madurapperuma ${ }^{1 *}$, P. G. Oduor ${ }^{2}$, K. A. J. M. Kuruppuarachchi ${ }^{3}$, D. N. N. \\ Wijayawardene ${ }^{4}$, and J. U. Munasinghe ${ }^{5}$
}

${ }^{1}$ Department of Forestry and Natural Resources, Purdue University, West Lafayette, IN 47906, USA.

${ }^{2}$ Department of Geosciences, North Dakota State University, P. O. Box 6050, Fargo, ND 58108, USA.

${ }^{3}$ Department of Botany, The Open University of Sri Lanka, P.O. Box 21, Nawala, Nugegoda

${ }^{4}$ IFS - Popham Arboretum, $2^{\text {nd }}$ Mile Post, Kandalama Road, Dambulla, Sri Lanka.

${ }^{5}$ Department of Zoology, The Open University of Sri Lanka, P.O. Box 21, Nawala, Nugegoda

Date Received: 24-05-2013 Date Accepted: 09-011-2013

\begin{abstract}
Repeated slash and burn cultivation creates wasteland with thorny shrubs, which then takes a long time to become secondary forests through serial stages of succession. Assisted natural regeneration through silvicultural management is a useful restoration method to accelerate succession. This survey evaluates the effectiveness of a simple silvicultural method for the rehabilitation of degraded lands to productive forest, thereby increasing floristic wealth. Field-based comparative analyses of floristic composition were carried out at a silviculturally managed forest (Popham Arboretum) and a primary forest (Kaludiyapokuna Forest Reserve) which is located in Dambulla in Sri Lanka. Floristic analysis was used to examine the effectiveness of silvicultural techniques for successful restoration of degraded forest in the dry zone. Nine $20 \mathrm{~m} \times 20 \mathrm{~m}$ plots in each forest were enumerated and the vegetation $\geq 10 \mathrm{~cm}$ girth at breast height was quantitatively analyzed. Cluster analysis resulted in five distinguishable clusters (two from Popham Arboretum and three from Kaludiyapokuna Forest Reserve). Similarity indices were generated to compare the plots within and between sites. Floristic similarity was higher in forest reserve plots compared to arboretum plots. A total of 72 plant species belonging to 60 genera and 26 families were recorded from the study sites. Of the recorded species, Grewia damine and Syzygium cumini (Importance Value Index, IVI $=24$ and 23 respectively) were the ecologically co-dominant taxa at the Popham Arboretum. In contrast, Mischodon zeylanicus (IVI = 31), Schleichera oleosa $($ IVI $=25)$ and Diospyros ebenum (IVI $=21$ ) were the abundant taxa in the forest reserve.
\end{abstract}

Keywords: dry zone forest, floristics, silviculture, TWINSPAN classification

\section{Introduction}

The dry zone of Sri Lanka covers about four million hectares (60\% of the total island area) and extends over the north, north-central and eastern parts of the island (Perera et al., 1977). Of the total forest cover in Sri Lanka (25\%), dry zone forest comprises approximately 22\% (Gunatilleke and Gunatilleke, 1983). The dry zone forests of Sri Lanka have experienced a large-scale depletion of forestland from (a) slash-and-burn (swidden) cultivation (Sandika and Withana, 2010) and (b) illegal felling or selective logging of valuable timber trees (Perera, 2001). Natural regeneration of degraded lands is usually poor in

*Correspondence: bmadurap@purdue.edu

Tel: +94 112881269; Fax: +94112803470

ISSN 2235-9370 Print / ISSN 2235-9362 Online @2013 University of Sri Jayewardenepura 
these dry zone forests (Weerawardana, 1999) because of the infertile soil and impenetrable barriers of scrub to tree seedlings. Repeated slash-and-burn agriculture directly impacts soil fertility that is needed in enhancing re-colonization of indigenous seedlings from a soil seed bank. Therefore, restoration of degraded forests using established common methods, including reforestation, is very challenging (Weerawardana, 1999). To answer this challenge, artificial regeneration can be initiated. Artificial regeneration is a technique of enrichment planting or replanting and is widely practiced in Sri Lanka albeit with a limited number of available species to convert degraded lands to woodlands. For example, the Forest Department of Sri Lanka regularly carries out tree planting campaigns using fast growing exotic trees as gap fillers in forested areas. One of the adverse effects of this kind of strategy is the deliberate introduction of plants that can become invasive species. For instance, Leucaena leucocephala was introduced in Sri Lanka as a multipurpose tree species in the early 1980s to be used as wind buffers for farmsteads, but seedlings have emerged in forests of the southern province and have been prolific (Marambe et al., 2001).

A simple but effective method to accelerate natural regeneration as an alternative to artificial means was introduced by Popham in 1963 (Popham, 1993). Essentially, this method can be described as a simple low-cost silvicultural method that boosts Assisted Natural Regeneration (ANR) in converting deforested lands to more productive forests (Dilhan et al., 2010; Shono et al., 2007). The guiding principle behind the low-cost silvicultural method was not to plant seedlings of native trees, but to allow seeds of native trees present in the soil seed bank to germinate (Popham, 1993). This low-cost silvicultural method is ideal because it is cost effective and easy to implement for private forest landowners to convert their land into a mini-arboretum through forest stewardship programs. This is akin to in-situ conservation of indigenous trees, which ensures the wealth of biological diversity.

Silvicultural management can be viewed as a disturbance in the ecological sense, except that it is a directed influence with predictable consequences (Van Miegroet, 1986). For instance, uneven-aged management through mixed-species stands enhances not only structural diversity but also biological diversity (Lentz et al., 1989; Phillips and Abercrombie Jr, 1987). Changes in structure and function of the forest depend upon the type of silvicultural system employed (Boncina, 2000). Therefore, the following factors should be addressed before implementing a silvicultural practice: tree composition, patch pattern, growing stock, vertical structure of the vegetation, availability of resources, and species diversity.

In this paper, the floristic richness of a managed forest, which depends on endogenous and exogenous influences, including human intervention, was compared to the floristic richness of a forest reserve to evaluate the effectiveness of silvicultural treatments to accelerate serial follow-up stages to bring back the forest. The specific aim of this study was to compare the structure and composition of the vegetation in the two forests using plot sampling.

\section{Methodology}

\subsection{Study area}

The main study site for this preliminary survey was the Popham Arboretum, which has been silviculturally managed for over four decades. The Popham Arboretum is located in the central province of Sri Lanka in the Matale district. It is about $2.9 \mathrm{~km}$ from the Kandalama-Dambulla Road. The total extent of the Popham Arboretum is 14.4 ha comprising 10.8 ha of woodland and 3.6 ha known as arboretum forest (Figure 1). The Kaludiyapokuna Forest Reserve (KFR) was selected for comparison. The reserve is located approximately $6 \mathrm{~km}$ from the arboretum and due east of Polonnaruwa Road and north of Kandalama Reservoir (Figure 1). KFR houses an $8^{\text {th }}-9^{\text {th }}$ century monastery complex and caves with preChristian period paintings and inscriptions, and several ponds, and it is protected as a historical site as well as government reserve since 1990 (IUCN, 1997). The vegetation at the forest reserve site can be described as a dry mixed evergreen forest characterized by both deciduous and evergreen dry zone plants. 
The annual rainfall is $1,520 \mathrm{~mm}$ and the average temperature is $29.5^{\circ} \mathrm{C}$ (Cramer, 1993). The major land use types in Dambulla study area are scrubland, homestead, forest, and paddy (Visvanathan, 2009). The population in Dambulla city is 72,082 in 2012 and the population density is 162 persons $/ \mathrm{km}^{2}$.

\subsection{Vegetation sampling}

Eighteen random $20 \mathrm{~m} \times 20 \mathrm{~m}$ plots were sampled for flora with nine plots in the arboretum and nine plots in the forest reserve. Four of the arboretum plots were in an area designated as dry-mixed/evergreen forest, while the rest ( 5 plots) were selected from the woodland area (Figure 1). The dry mixed evergreen forest is dominated by Manilkara-Chloroxylon series and Chloroxylon-Vitex-Berrya-Schleichera series (Gaussen et al., 1964). In contrast, plots from the KFR (see also Figure 1) were selected by using an altitudinal gradient criterion ranging from a lower valley area to a gentle sloping area. Individuals $\geq 10 \mathrm{~cm}$ girth at breast height (gbh) (1.3 m above the ground) were enumerated within the plots and were labelled with numbered aluminium tags. Vegetation characteristics, which included density and gbh of all woody species, were recorded. The density and basal area of plant species were used to interpret the horizontal distribution of the vegetation. The Importance Value Indices (IVI) of all the species were calculated using relative basal area (RBA) and relative density (RD) for individuals (Dilhan et al., 2006). IVI is related to RBA and RD by the following equation:

$$
\% \mathrm{IVI}=\% \mathrm{RBA}+\% \mathrm{RD}
$$

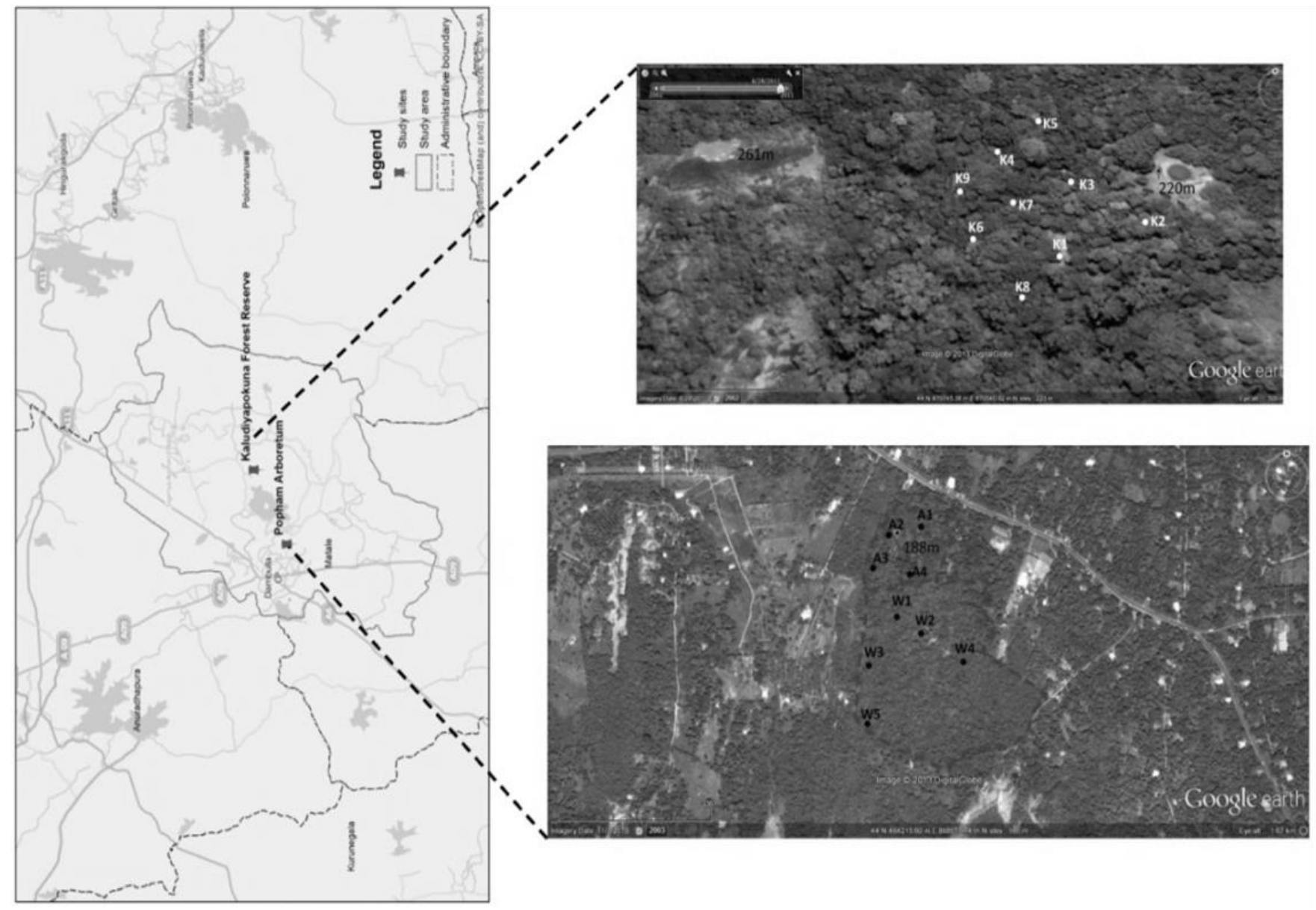

Figure 1: Map showing the sampling plots in the Popham Arboretum and KFR located in Dambulla in Central province of Sri Lanka. 
A vegetation classification based on Two Way Indicator Species Analysis (TWINSPAN) was performed with species abundance data from two sites using PCORD 4 software (MJM software, Gleneden Beach, Oregon, USA). Species composition and community structure between the restored site and the natural forest was compared by computing mean similarity indices using the Bray-Curtis similarity index (Sorensen's index) with Primer ${ }^{\circledR} 5$ software (Magurran, 2004).

\section{Results and Discussion}

Sri Lanka ranks second among tropical Asian countries in forest degradation, with $40 \%$ of forests subjected to degradation (Chokkalingam, 2001). Most of the dry zone forests in Sri Lanka are of secondary origin and severely degraded due to shifting cultivation resulting in thorny scrubland (Dilhan et al., 2002; Perera, 2001; Samarasinghe, 1995). However, despite Sri Lanka's high ranking and its severe forest degradation, there is very little literature addressing the different types of secondary forests and the characteristics that distinguish a secondary forest from a primary forest (De Jong et al., 2001). Generally, human induced forest fragments are expected to result in low species richness (McLennan and Plumptre, 2012), but it was hypothesized that a silviculturally managed secondary forest harbors more species than forest fragments. Therefore, a three-way comparison was constructed; it compared the floristic richness of rehabilitated secondary forest, namely the Popham Arboretum, to nearby natural forest and with previous floristic studies.

\subsection{Species richness}

A total of 72 plant species belonging to 60 genera and 26 families were enumerated for the Popham Arboretum and KFR (Appendix 1). Species richness in the arboretum was comprised of 48 plant species, 42 genera, and 21 families, whereas KFR was comprised of 33 plant species, 23 genera, and 16 families. Of the recorded species in the arboretum, 35 were trees and 13 were shrubs, whereas at KFR 23 were tree species and 8 were shrub species. Two endemic species, Diplodiscus verrucosus and Xylopia nigricans, were encountered at the arboretum and forest reserve respectively.

Species richness of the Popham Arboretum was considerably high; this indicated that the silvicultural management enhanced not only plant diversity but also rehabilitated ambient soils to recolonize juveniles (Popham, 1993). When the economic significance of flora was considered, it was found that plants at the arboretum harboured the highest economic value (see appendix 1); 27 had medicinal value, 15 had timber value, and 7 had both timber and medicinal value (Cramer, 1993; Dilhan et al., 2006). This supported the Dilhan et al. (2006) study, which reported 45 plants with medicinal value, 14 with timber value, and 7 with both timber and medicinal value out of 101 species belonging to 91 genera and 42 families at the Popham Arboretum. These results are also comparable with the floristic study on understory vegetation at the Hurulu Forest Reserve, which documented 49 medicinal plants out of 81 species belonging to 73 genera and 37 families (Solangaarachchi and Perera, 1993). Furthermore, Vandercone et al. $(2011 ; 2012)$ recorded 73 species belonging to 58 genera and 30 families for 59 sampling plots at the KFR. In contrast to the arboretum findings, only 5 medicinal and 3 timber plants were recorded at KFR. This obvious difference between the recorded numbers of arboretum and KFR species may be a sampling issue, because the sample size may not have been sufficient to record all species.

\subsection{Species and family importance values}

In the Popham Arboretum, Grewia damine (IVI = 24 / 200) and Syzygium cumini (IVI = 23 / 200) were the ecologically co-dominant species. In contrast, the most dominant species in the KFR was Mischodon zeylanicus (IVI = 31) followed by Schleichera oleosa $($ IVI $=25)$ and Diospyros ebenum (IVI $=21$ ). The leading family in the arboretum was Tiliaceae (IVI = 39 and $2 \mathrm{spp}$.), whereas Euphorbiaceae (IVI = 58, 4 spp.) and Sapindaceae (IVI = 45, 4 spp.) were the co-dominant families in the forest reserve. 
Species richness in the arboretum ranged from $4-6$ for Fabaceae, Rutaceae and Rubiaceae with IVI values ranging from $16-18$. However, species richness with four species in the KFR was recorded only in Sapindaceae and Euphorbiaceae with IVI values ranging from 45 to 58.

\subsection{Density, basal area, and population size}

The number of individuals per plot ranged from 36 - 115 at the Popham Arboretum and from $31-$ 108 at the KFR (Figure 2). The number of species recorded ranged from 16-23 in the arboretum and $9-$ 17 in the forest reserve. The arboretum plot A3 had the highest number of individuals (115) with 23 species recorded. In contrast, the arboretum plot A1 had the lowest number of individuals (36) recorded with a comparatively high species richness (Figure 2). The average number of individuals in the woodland plots (W1 - W5) was higher $(69 \pm 11)$ compared to the arboretum plots A1 - A4 (62 \pm 36$)$. At the forest reserve, the average number of individuals was $58 \pm 27$.

The stem density for all woody taxa measured at $\geq 10 \mathrm{~cm}$ gbh was $2,433 \pm 71$ stems per hectare in the arboretum and only 1,442 \pm 70 stems per hectare at the forest reserve. The density of individuals was the highest at $0-10 \mathrm{~cm}$ dbh size class at both sites (arboretum $=1978 \pm 18 ; \mathrm{KFR}=858 \pm 11$ ). The total basal area for the plots sampled at the arboretum was $118 \pm 1 \mathrm{~m}^{2} /$ ha, while it was $505 \pm 11 \mathrm{~m}^{2} / \mathrm{ha}$ at the forest reserve. The forest reserve recorded the highest basal area $\left(335 \pm 25 \mathrm{~m}^{2} / \mathrm{ha}\right)$ in the dbh size class greater than $40 \mathrm{~cm}$, whereas the arboretum recorded the highest basal area $\left(44 \pm 0.4 \mathrm{~m}^{2} / \mathrm{ha}\right)$ for $10-20 \mathrm{~cm}$ dbh size class. The highest species richness was recorded for the 2-10 population size class for both Popham Arboretum (18 spp.) and KFR (16 spp.).

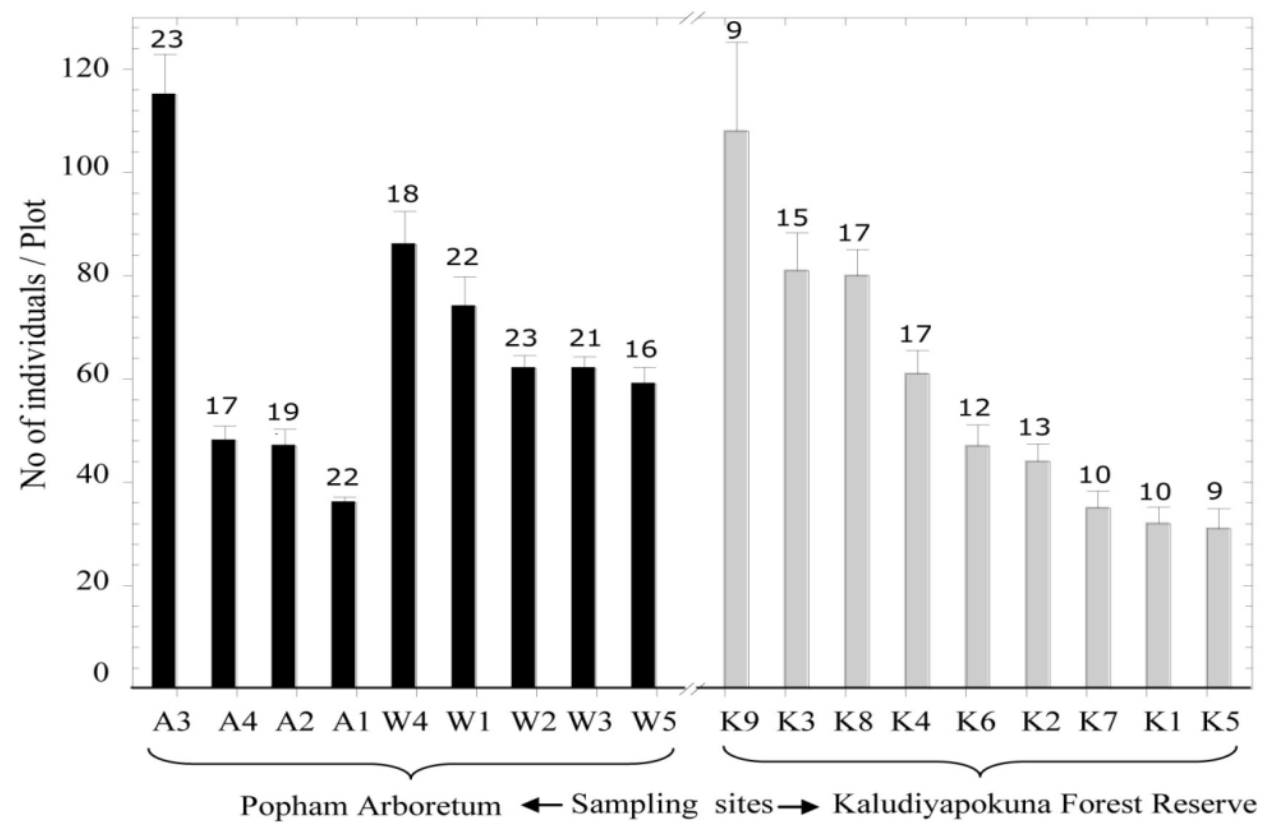

Figure 2. Number of individuals per plot sampled at Popham Arboretum and KFR. The figure represents plots A1 - A4 and W1 - W5 from the Popham Arboretum and plots K1 - K9 from the KFR. Number of species recorded for each plot is displayed above the error bars.

The average stem density of plants per plot was high in the silviculturally managed forest compared to the natural forest. The densities of individuals, especially in the lower dbh size classes in the arboretum, were higher compared to the forest reserve since the arboretum was prone to serial slash-andburn cultivation. In contrast, the basal area of plants at KFR was four times larger than at the arboretum due to the increased presence of more mature plants. These results indicated that the arboretum is still in 
the young climax stage with heterogeneous vegetation, which necessitates conservation management and the planning of similar forests.

\subsection{Trends and relationships}

The Two Way Indicator Species Analysis (TWINSPAN) is summarized in Figure 3. Based on floristic composition, the 18 plots were classified into five clusters. The first division of the classification tree divided into two groups of nine plots with an eigen-value of $E=0.762$. The first group comprised of woodland and arboretum plots, showed indicator species of Chloroxylon swietenia (Buruta) and Diospyros habarala (Kaluhabarala). The subgroup A2 plot's indicator species $(\mathrm{E}=0.293)$ was Acronychia pedunculata (Ankenda). The subgroup A1 $(\mathrm{E}=0.274)$ was characterized by the indicator species, Diospyros malabarica (Timbiri). Four woodland plots (W2 - W5) formed the third subgroup. The fourth subgroup consisted of two arboretum plots (A3 and A4) and a single woodland (W1) plot.

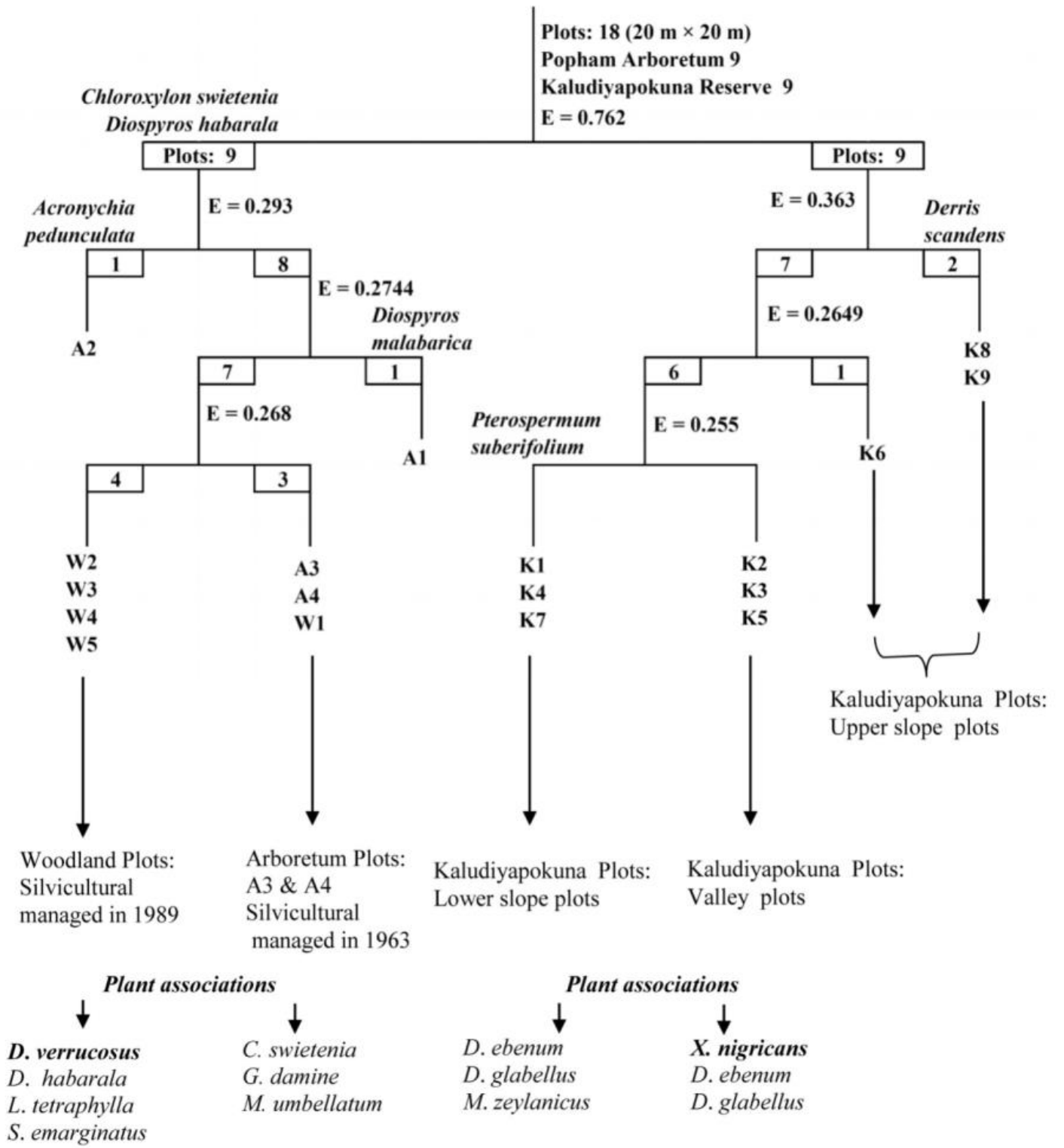

Figure 3: Classification (Two-Way Indicator Species Analysis) of 18 plots sampled in the Popham Arboretum (Arboretum - 4 plots labelled A1- A4, woodland - 5 plots labelled W1 - W5) and KFR (plots labelled K1 - K9) using species abundance data. The indicator species and the eigen values at each division are also annotated. Bold text indicates endemic species. 
The second main group ( $E=0.762$ ) also separated into four distinguishable subgroups comprising nine plots located in the KFR. The indicator species, Derris scandens (Kala-wel), formed the first subgroup $(E=0.363)$ : $\mathrm{K} 8$ and $\mathrm{K} 9$. For the second subgroup $(E=0.265)$ only a single plot, K6, could be assigned. The first and second subgroups were classified as upper slope plots. The third subgroup consisted of K2, K3, and K5, which were identified as valley plots. The fourth subgroup was represented by plots K1, K4, K7, and the indicator species, Pterospermum suberifolium (Welang). These plots were classified as lower slope plots.

In the TWINSPAN diagram, the arboretum and the woodland plots were separated as distinct plant communities (Figure 3). For example, Chloroxylon-Grewia-Memecylon and Diplodiscus-DiospyrosLepisanthes-Sapindus were distinguished as plant communities in the arboretum and woodland, respectively. KFR was associated with the Diospyros-Xylopia- Dimorphocalyx-Mischodon plant community. Species composition of the two sites was not comparable due to the elevation gradient. For example, Xylopia nigricans, which was dominant at $225 \mathrm{~m}$ elevation in the valley plots of KFR (Figure 2), was not recorded in the arboretum. However, Mischodon zeylanicus, the dominant species at the lower slope plots of KFR, was found at the rock outcrop of the Popham Arboretum (Cramer, 1993; Dilhan et al., 2006; Popham, 1993).

As shown in the TWINSPAN diagram, the lower slope plots and the valley plots of KFR were closely lumped together at the base of the cluster and shared two dominant species, namely D. ebenum and D. glabellus. In contrast, upper slope plots (K8 and K9) were typically characterized by a liana, Derris scandens. As a silvicultural treatment, climbers like these were banned from Popham Arboretum to assist natural regeneration of native trees (Dilhan et al., 2010; Popham, 1993).

The derived Bray-Curtis similarity index yielded very high plant abundance similarity estimates for the natural forest (Table 1). Woodland plots (W1 to W5) also showed relatively high similarity among the plots (with values ranging from 0.33 to 0.70 ). The arboretum plots had lower similarity indices compared to woodland and natural forest. In addition, the similarity index for arboretum plot A3 was low compared to plots A1, A2, and A4.

Table 1: Comparison of plots within and between sites using the Bray-Curtis similarity index (Sorensen's index). The Bray-Curtis similarity index used mean abundance data of species of 18 plots sampled in the Popham Arboretum (Arboretum - 4 plots labelled A1- A4, woodland - 5 plots labelled W1 - W5) and KFR (plots labelled K1 - K9).

\begin{tabular}{|c|c|c|c|c|c|c|c|c|c|c|c|c|c|c|c|c|c|c|}
\hline Plot & $\mathrm{A} 1$ & A2 & A3 & A4 & W1 & W2 & W3 & W4 & W5 & K1 & K2 & K3 & K4 & K5 & K6 & K7 & K8 & K9 \\
\hline Al & 1 & & & & & & & & & & & & & & & & & \\
\hline A2 & 0.30 & 1 & & & & & & & & & & & & & & & & \\
\hline A3 & 0.24 & 0.13 & 1 & & & & & & & & & & & & & & & \\
\hline A4 & 0.34 & 0.33 & 0.34 & 1 & & & & & & & & & & & & & & \\
\hline W1 & 0.31 & 0.16 & 0.39 & 0.52 & 1 & & & & & & & & & & & & & \\
\hline W2 & 0.47 & 0.36 & 0.31 & 0.38 & 0.42 & 1 & & & & & & & & & & & & \\
\hline W3 & 0.30 & 0.29 & 0.21 & 0.23 & 0.33 & 0.59 & 1 & & & & & & & & & & & \\
\hline W4 & 0.20 & 0.24 & 0.29 & 0.33 & 0.34 & 0.41 & 0.70 & 1 & & & & & & & & & & \\
\hline W5 & 0.30 & 0.09 & 0.19 & 0.32 & 0.42 & 0.39 & 0.42 & 0.45 & 1 & & & & & & & & & \\
\hline K1 & 0.14 & 0.04 & 0.09 & 0.03 & 0.07 & 0.09 & 0.06 & 0.07 & 0.02 & 1 & & & & & & & & \\
\hline K2 & 0.13 & 0.06 & 0.05 & 0.02 & 0.06 & 0.11 & 0.12 & 0.09 & 0.04 & 0.63 & 1 & & & & & & & \\
\hline K3 & 0.11 & 0.03 & 0.04 & 0.00 & 0.04 & 0.10 & 0.11 & 0.08 & 0.02 & 0.35 & 0.53 & 1 & & & & & & \\
\hline K4 & 0.13 & 0.05 & 0.14 & 0.05 & 0.12 & 0.14 & 0.15 & 0.14 & 0.05 & 0.52 & 0.45 & 0.44 & 1 & & & & & \\
\hline K5 & 0.11 & 0.02 & 0.05 & 0.00 & 0.04 & 0.06 & 0.06 & 0.06 & 0.02 & 0.41 & 0.38 & 0.31 & 0.69 & 1 & & & & \\
\hline K6 & 0.13 & 0.06 & 0.06 & 0.02 & 0.06 & 0.12 & 0.11 & 0.09 & 0.02 & 0.59 & 0.52 & 0.48 & 0.38 & 0.25 & 1 & & & \\
\hline K7 & 0.14 & 0.04 & 0.08 & 0.03 & 0.07 & 0.12 & 0.10 & 0.09 & 0.02 & 0.42 & 0.50 & 0.40 & 0.65 & 0.59 & 0.41 & 1 & & \\
\hline K8 & 0.11 & 0.03 & 0.12 & 0.03 & 0.10 & 0.12 & 0.15 & 0.13 & 0.05 & 0.41 & 0.39 & 0.41 & 0.57 & 0.41 & 0.30 & 0.32 & 1 & \\
\hline K9 & 0.06 & 0.02 & 0.04 & 0.00 & 0.02 & 0.10 & 0.10 & 0.08 & 0.02 & 0.27 & 0.24 & 0.43 & 0.30 & 0.16 & 0.30 & 0.14 & 0.58 & 1 \\
\hline
\end{tabular}




\section{Conclusions}

Over-exploitation of dry zone forest through shifting cultivation affects loss of biodiversity in Sri Lanka. Understanding biogeography and floristic wealth of degraded forests is important prior to the introduction of any rehabilitation or restoration program. This survey assesses the implementation of long-term silvicultural management practices and their contribution to floristic wealth. This floristic survey showed that the silviculturally managed forest was equally important to natural forest promising rich biota. Therefore, the Forest Department should apply this silvicultural method to the restoration of degraded shifting cultivation lands in Sri Lanka to conserve native plants. In addition, the biological wealth of the arboretum makes it advantageous to link it with neighbouring forests like KFR and Araula Hill through restoration corridors.

Acknowledgements: The authors extend their gratitude and appreciation to Mr. Sam Popham, Mr. J. Amarasinghe, Curator of Popham Arboretum, Ruk Rakaganno Current Manager of Popham Arboretum, and the Institute of Fundamental Studies. The authors wish to thank anonymous reviewers for their valuable comments and suggestions to improve the manuscript.

\section{References}

Boncina, A. 2000. Comparison of structure and biodiversity in the Rajhenav virgin forest remnant and managed forest in the Dinaric Region of Slovenia. Global Ecology and Biogeography 9:201-211.

Chokkalingam, U. 2001. Rehabilitation of degraded lands in tropical Asia: a synthesis. Journal of Tropical Forest Science 13(4):816-831.

Cramer, L.H. 1993. A forest arboretum in the dry zone. Institute of Fundamental Studies, Sri Lanka.

De Jong, W., Chokkalingam, U. and Smith, J. 2001. Tropical secondary forest in Asia: Introduction and synthesis. Journal of Tropical Forest Science 13:563-576.

Dilhan, M.A.A.B., Yakandawala, D., Gunatilleke, C.V.S. and Bambaradeniya, C.N.B. 2002. Structure and composition of a scrubland vegetation in the lower Walawe basin irrigation extension area in Sri Lanka. Ceylon Journal of Science (Biological Science) 30: 125-145.

Dilhan, M.A.A.B., Weerasinghe, T.D. and Amarasinghe, J. 2006. Structure and composition of vegetation in the IFS - Popham Arboretum, Dambulla. Wild Lanka 1:90-102.

Dilhan, M.A.A.B., Amarasinghe, J. and Wijewardene, D.N.N. 2010. Building sustainable botanic gardens: a simple silvicultural method adopted to haven certain wood trees into productive arboretum in the dry zone of Sri Lanka. Proceedings of the Fourth Global Botanic Gardens Congress BGCI, 14.www.bgci.org/files/Dublin2010/papers/Dilhan-M-A-A-B.pdf Access 01 December 2010.

Gaussen, H., Legris, P., Viart, M. and Labrouse, L. 1964. International Map of the vegetation: Ceylon (1: 1,000,000). French Institute of Pondicherry, India.

Gunatilleke, I.A.U.N. and Gunatilleke, C.V.S. 1983. Conservation of Natural Forests in Sri Lanka. The Sri Lanka Forester 16 (1 \& 2): 39-56.

IUCN [The World Conservation Union]. 1997. Designing an optimum protected areas system for Sri Lanka's natural forests. IUCN/FAO1:1-399.

Lentz, R.J., Sims, D.H. and Ince, P.J. 1989. Are our traditional attitudes restricting forestry management options? In: Waldrop, T. A. (Ed.) Proceedings of pine-hardwood mixtures: A symposium on management and ecology of the type, General Technical Rep. SE-58, U.S.D.A. Forest Service, Southeastern Forest Experiment Station, Asheville, NC. pp. 20-24.

Magurran, A.E. 2004. Measuring biological diversity. Blackwell Publishing: Oxford, United Kingdom. 
Marambe, B., Bambaradeniya, C., Pushpa Kumara, D.K. and Pallewatta, N. 2001. Human dimensions of invasive alien species in Sri Lanka. In: Mcneely, J.A. (Ed.) The great reshuffling human dimensions of invasive alien species, IUCN, Glard, Switzerland and Cambridge, UK. pp. 135-142.

McLennan, M.R. and Plumptre, A.J. 2012. Protected apes, unprotected forest: composition, structure and diversity of riverine forest fragments and their conservation value in Uganda. Tropical Conservation Science 5:79-103.

Perera, G.A.D. 2001. The secondary forest situation in Sri Lanka: A review. Journal of Tropical Forest Science 13(4):768-785.

Perera, W.R.H. 1977. The development of the forest resources of Sri Lanka. The Sri Lanka Forester 13(1\&2): 5-8.

Phillips, D.R., Abercrombie Jr., J.A. 1987. Pine-hardwood mixtures: A new concept in regeneration. Southern Journal of Applied Forestry 11(4): 192-197.

Popham, F.H. 1993. Dambulla. A Sanctuary of tropical trees. Sam Popham foundation, UK.

Samarasinghe, J. 1995. Regeneration dynamics of silviculturally assisted dry zone scrub vegetation at Dambulla arboretum. Proceedings of the Annual Forestry Symposium, Department of Forestry and Environment Science University of Sri Jayawardanapura, Sri Lanka, 291-299.

Sandika, A.L. and Withana, N.R.P. 2010. Economic analysis of chena cultivation in Monaragala district, Sri Lanka. Proceedings of the Annual Forestry Symposium, Dept. of Forestry and Environment Science, University of Sri Jayewardenepura, Sri Lanka, 15:350-356.

Shono K., Cadaweng, E.A. and Durst, P.B. 2007. Application of assisted natural regeneration to restore degraded tropical forestlands. Restoration Ecology 15(4):620-626.

Solangaarachchi, S.M. and Perera, B.M.S. 1993. Floristic composition and medicinally important plants in the understory of the tropical dry mixed evergreen forest at the Hurulu reserve of Sri Lanka. Journal of National Science Council Sri Lanka 21:209-226.

Vandercone, R. 2011. Dietary Shifts, Niche Relationships and Interspecific Competition in the Sympatric Grey Langur (Semnopithecus entellus) and the Purple-Faced Langur (Trachypithecus vetulus) in Sri Lanka. Ph.D. Dissertation.Washington University, St. Louis, USA.

Vandercone, R.P., Dinadh, C., Wijethunga, G., Ranawana, K. and Rasmussen, D.T. 2012. Dietary diversity and food selection in Hanuman Langurs (Semnopithecus entellus) and Purple faced langurs (Trachypithecus vetulus) in the Kaludiyapokuna forest reserve in the dry zone of Sri Lanka. International Journal of Primatology 33:1382-1405.

Van Miegroet, M. 1986. Bioecological aspects of silvicultural intervention. Forest Environment and Silviculture $18^{\text {th }}$ IUFRO World Congress, Ljubljan, Div. 1(1):273-285.

Visvanathan, C., Setiadi, T., Herath, G. and Han, S. 2009. Eco-industrial clusters in urban-rural fringe areas: A strategic approach for integrated environmental and economic planning. Asian Institute of Technology, 45-69.

Weerawardana, N.D.R. 1999. Natural regeneration of some dry zone forest species assisted by silvicultural management in dry zone woodland at Dambulla. The Sri Lanka forester 23(3 and 4):7-17. 
Appendix 1: Exhaustive species list of identified vegetation

\begin{tabular}{|c|c|c|c|c|c|}
\hline Species/Family & $\begin{array}{l}\text { Species } \\
\text { Code }\end{array}$ & Local Name & $\begin{array}{l}\text { Economic } \\
\text { Value }\end{array}$ & Life Form & Site \\
\hline \multicolumn{6}{|l|}{ Annonaceae } \\
\hline Polyalthia coffeoides & Poco & Omara & & $\mathrm{T}$ & $\mathrm{K}$ \\
\hline Polyalthia korinti & Poko & Ul-kenda & M & $\mathrm{T}$ & $\mathrm{K} *$ \\
\hline Xylopia nigricans & Xyni & Heen-kenda & & $\mathrm{T}$ & $\mathrm{K}$ \\
\hline Apocynaceae & & & & & \\
\hline Alstonia scholaris & Alsc & Ruk-attana & & $\mathrm{T}$ & $\mathrm{K} *$ \\
\hline \multicolumn{6}{|l|}{ Boraginaceae } \\
\hline Cordia dichotoma & Codi & Lolu & & $\mathrm{T}$ & A \\
\hline Ehretia laevis & Ehla & Walangasal & M & $\mathrm{T}$ & A \\
\hline Capparaceae & & & & & \\
\hline $\begin{array}{l}\text { Capparis zeylanica } \\
\text { Celastraceae }\end{array}$ & Caze & Sudu-welangiriya & M & $\mathrm{C}$ & $\mathrm{A} / \mathrm{K}$ \\
\hline $\begin{array}{l}\text { Pleurostylia opposita } \\
\text { Clusiaceae }\end{array}$ & Plop & Panakka & $\mathrm{T}$ & $\mathrm{T}$ & A \\
\hline $\begin{array}{l}\text { Mesua ferrea } \\
\text { Ebenaceae }\end{array}$ & Mefe & $\mathrm{Na}$ & & $\mathrm{T}$ & $\mathrm{K}^{*}$ \\
\hline Diospyros ebenum & Dieb & Kaluwara & $\mathrm{T}$ & $\mathrm{T}$ & $\mathrm{A} / \mathrm{K}$ \\
\hline Diospyros habarala & Diha & Kaluhabarala & & $\mathrm{T}$ & A \\
\hline Diospyros malabarica & Dima & Timbiri & M & $\mathrm{T}$ & A \\
\hline Diospyros oppositifolia & Diop & Kalu-mediriya & $\mathrm{T}$ & $\mathrm{T}$ & A \\
\hline Diospyros ovalifolia & Diov & Kunumella & & $\mathrm{T}$ & $\mathrm{K} *$ \\
\hline \multicolumn{6}{|l|}{ Euphorbiaceae } \\
\hline Bridelia retusa & Brre & Kaetakela & $\mathrm{M} / \mathrm{T}$ & $\mathrm{T}$ & A \\
\hline Dimorphocalyx glabellus & Digl & Welikaha & & $\mathrm{S}$ & $\mathrm{A} / \mathrm{K}$ \\
\hline Drypetes sepiaria & Drse & Wira & & $\mathrm{T}$ & $\mathrm{K} *$ \\
\hline Flueggea leucopyrus & Flle & Heen-katu-pila & M & $\mathrm{S}$ & A \\
\hline Mischodon zeylanicus & Mize & Tammanna & & $\mathrm{T}$ & $\mathrm{K} *$ \\
\hline Phyllanthus indicus & Phin & Karaw & & $\mathrm{T}$ & A \\
\hline $\begin{array}{l}\text { Phyllanthus polyphyllus } \\
\text { Fabaceae }\end{array}$ & Phpo & Kuratiya & & $\mathrm{S}$ & $\mathrm{A} / \mathrm{K}$ \\
\hline Bahunia tomentosa & Bato & Petan & & $\mathrm{S}$ & $\mathrm{K} *$ \\
\hline Bauhinia racemosa & Bara & Maila & M & $\mathrm{T}$ & A \\
\hline Cassia fistula & Cafi & Ehela & $\mathrm{M} / \mathrm{T}$ & $\mathrm{T}$ & A \\
\hline Cassia roxburghii & Caro & Ratu-wa & M & $\mathrm{T}$ & A \\
\hline Derris scandens & Desc & Kala-wel & & $\mathrm{C}$ & $\mathrm{K} *$ \\
\hline Dichrostachys cinerea & Dici & Andara & M & $\mathrm{S}$ & A \\
\hline Entada pusaetha & Enpu & Pus-wael & M & $\mathrm{C}$ & $\mathrm{K}$ \\
\hline $\begin{array}{l}\text { Tamarindus indica } \\
\text { Flacourtiaceae }\end{array}$ & Tain & Siyambala & $\mathrm{M} / \mathrm{T}$ & $\mathrm{T}$ & A \\
\hline $\begin{array}{l}\text { Flacourtia indica } \\
\text { Hernandiaceae }\end{array}$ & Flin & Katukutundu & & $\mathrm{S}$ & A \\
\hline $\begin{array}{l}\text { Gyrocarpus americanus } \\
\text { Lauraceae }\end{array}$ & Gyam & Diya-labu & & $\mathrm{T}$ & $\mathrm{K} *$ \\
\hline Alseodaphne semecarpifolia & Alse & Wewarani & $\mathrm{T}$ & $\mathrm{T}$ & A \\
\hline Cryptocarya $\mathrm{sp}$. & Cryp & Gal-mora & & $\mathrm{T}$ & $\mathrm{K}$ \\
\hline
\end{tabular}




\begin{tabular}{|c|c|c|c|c|c|}
\hline Species/Family & $\begin{array}{c}\text { Species } \\
\text { Code }\end{array}$ & Local Name & $\begin{array}{l}\text { Economic } \\
\text { Value }\end{array}$ & Life Form & Site \\
\hline $\begin{array}{l}\text { Loganiaceae } \\
\text { Abelmoschus angulosus }\end{array}$ & Aban & Kapu-kinissa & & $\mathrm{S}$ & $\mathrm{K}$ \\
\hline $\begin{array}{l}\text { Melastomataceae } \\
\text { Memecylon umbellatum } \\
\text { Meliaceae }\end{array}$ & Meum & Kora-kaha & M & $\mathrm{T}$ & A \\
\hline Azadiracta indica & Azin & Kohomba & $\mathrm{M} / \mathrm{T}$ & $\mathrm{T}$ & A \\
\hline $\begin{array}{l}\text { Chukrasia tabularis } \\
\text { Moraceae }\end{array}$ & Chta & Hulunhik & $\mathrm{M} / \mathrm{T}$ & $\mathrm{T}$ & A \\
\hline Ficus amplissima & Fiam & Ela-nuga & & $\mathrm{T}$ & $\mathrm{K} *$ \\
\hline Ficus heterophylla & Fihe & Wal-ehetu & & $\mathrm{T}$ & $\mathrm{K}$ \\
\hline $\begin{array}{l}\text { Streblus asper } \\
\text { Myrtaceae }\end{array}$ & Stas & Nitul & M & $\mathrm{T}$ & A \\
\hline Eugenia bracteata & Eubr & Daeduwa & & $\mathrm{T}$ & A \\
\hline $\begin{array}{l}\text { Syzygium cumini } \\
\text { Ochnaceae }\end{array}$ & Sycu & Ma-dan & $\mathrm{M} / \mathrm{T}$ & $\mathrm{T}$ & A \\
\hline $\begin{array}{l}\text { Ochna obtusata } \\
\text { Rubiaceae }\end{array}$ & Ocob & Galkera & & $\mathrm{S}$ & A \\
\hline Benkara malabarica & Bema & Getakula & & $\mathrm{S}$ & A \\
\hline Canthium coromandelicum & Caco & Kara & M & $\mathrm{S}$ & A \\
\hline Canthium dicoccum & Cadi & Bokutu & M & $\mathrm{T}$ & A \\
\hline Catunaregam spinosa & Casp & Kukurman & M & $\mathrm{S}$ & A \\
\hline Ixora pavetta & Ixpa & Godaratmal & M & $\mathrm{T}$ & A \\
\hline $\begin{array}{l}\text { Mitragyne parvifolia } \\
\text { Rutaceae }\end{array}$ & Mipa & Helamba & $\mathrm{M} / \mathrm{T}$ & $\mathrm{T}$ & A \\
\hline Acronychia pedunculata & Acpe & Ankenda & M & $\mathrm{T}$ & A \\
\hline Chloroxylon swietenia & Chsw & Buruta & $\mathrm{T}$ & $\mathrm{T}$ & A \\
\hline Glycosmis mauritiana & Glma & Bol-pana & & $\mathrm{S}$ & $\mathrm{K} *$ \\
\hline Glycosmis pentaphylla & Glpe & Dodan-pana & M & $\mathrm{T}$ & $\mathrm{K}$ \\
\hline Limonia acidissima & Liac & Divul & M & $\mathrm{T}$ & A \\
\hline Murraya exotica & Muex & Etteriya & & $\mathrm{S}$ & $\mathrm{K}$ \\
\hline $\begin{array}{l}\text { Pleiospermium alatum } \\
\text { Sapindaceae }\end{array}$ & Plal & Tunpat-kurudu & M & $\mathrm{S}$ & A \\
\hline Allophylus serratus & Alse & Kobbe & M & $\mathrm{S}$ & $\mathrm{A} / \mathrm{K}$ \\
\hline Dimocarpus longan & Dilo & Mora & & $\mathrm{T}$ & $\mathrm{K} *$ \\
\hline Lepisanthes tetraphylla & Lete & Dambu & & $\mathrm{T}$ & $\mathrm{A} / \mathrm{K}$ \\
\hline Sapindus emarginatus & Saem & Penela & & $\mathrm{T}$ & A \\
\hline $\begin{array}{l}\text { Schleichera oleosa } \\
\text { Sapotaceae }\end{array}$ & Scol & Kon & & $\mathrm{T}$ & $\mathrm{A} / \mathrm{K}$ \\
\hline $\begin{array}{l}\text { Manilkara hexandra } \\
\text { Sterculiaceae }\end{array}$ & Mahe & Palu & $\mathrm{T}$ & $\mathrm{T}$ & A \\
\hline Pterospermum suberifolium & Ptsu & Welang & & $\mathrm{T}$ & $\mathrm{A} / \mathrm{K}$ \\
\hline $\begin{array}{l}\text { Sterculia balanghas } \\
\text { Tiliaceae }\end{array}$ & Stba & Nawa & & $\mathrm{T}$ & $\mathrm{K}$ \\
\hline Berrya cordifolia & Beco & Halmilla & $\mathrm{T}$ & $\mathrm{T}$ & $\mathrm{K} *$ \\
\hline Diplodiscus verrucosus & Dive & Dik-wenna & & $\mathrm{T}$ & A \\
\hline Grewia damine & Grda & Damunu & & $\mathrm{T}$ & $\mathrm{A} / \mathrm{K}$ \\
\hline Grewia rothii & Grro & Bora-damunu & & $\mathrm{T}$ & $\mathrm{K} *$ \\
\hline
\end{tabular}


Madurapperuma et al., /Journal of Tropical Forestry and Environment Vol. 3, No. 02 (2013) 11-22

\begin{tabular}{lclccc}
\hline \multicolumn{1}{c}{ Species/Family } & $\begin{array}{c}\text { Species } \\
\text { Code }\end{array}$ & Local Name & $\begin{array}{c}\text { Economic } \\
\text { Value }\end{array}$ & Life Form & Site \\
\hline $\begin{array}{l}\text { Verbenaceae } \\
\text { Premna tomentosa }\end{array}$ & Prto & Seru & & & \\
Vitexaltissima & Vial & Milla & T & T & A \\
\hline
\end{tabular}

(Economic value: $\mathrm{M}=$ Medicine, $\mathrm{T}$ = Timber; Life Forms: $\mathrm{T}=$ Tree, $\mathrm{S}=$ Shrub, $\mathrm{C}=$ Climber;

Site: $\mathrm{A}=$ Arboretum, $\mathrm{K}=\mathrm{KFR}$ )

* Species recorded for the arboretum (Cramer,1993; Dilhan et al., 2006).

Bold text indicates endemic plants. 